\title{
Antioxidant and Anti-wrinkling Effects of Extracts from Vitex trifolia L.
}

\author{
Mi-Kyoung Lee $\cdot$ Dong-Hee Kim $\cdot$ Tae-Soon Park $\cdot$ Jun-Ho Son*

\section{만형자 추출물의 항산화 및 주름개선 효과}

이미경 · 김동희 - 박태순 · 손준호*

Received: 15 January 2015 / Accepted: 13 February 2015 / Published Online: 30 June 2015

(C) The Korean Society for Applied Biological Chemistry 2015

\begin{abstract}
In this study, the antioxidant and anti-wrinkling effects of fraction from Vitex trifolia L. were investigated. Among the fractions, ethyl acetate fraction showed the highest antioxidant activities in 1-1-diphenyl-2-picryl-hydrazyl, 2,2'-azino-bis(3ethylbenzothiazoine-6-sulfonic acid) radical scavenging and elastase inhibition with 76,89 , and $74 \%$, respectively, at a concentration of $1,000 \mu \mathrm{g} / \mathrm{mL}$. This fraction, at the concentration of $25 \mu \mathrm{g} / \mathrm{mL}$, inhibited $70 \%$ fibroblast cell viability and $86 \%$ the matrix metalloprotease (MMP)-1. In addition, the results from Western blot assay showed that this fraction $(25 \mu \mathrm{g} / \mathrm{mL})$ expressed the MMP-1 protein level by decreasing $50 \%$. The findings suggest that the ethyl acetate fraction from $V$. trifolia has great potential as a cosmeceutical ingredient with antioxidant and anti-wrinkling effects.
\end{abstract}

Keywords 1-1-diphenyl-2-picryl-hydrazyl $\cdot 2,2$ '-azino-bis(3ethylbenzothiazoline-6-sulfonic acid) $\cdot$ anti-wrinkle $\cdot$ elastase $\cdot$ matrix metalloprotease-1 - Vitex trifolia L.

M.-K. Lee $\cdot$ D.-H. Kim · T.-S. Park · J.-H. Son

Korea Promotion Institute for Traditional Medicine Industry, Gyeongbuk 712-260, Republic of Korea

*Corresponding author (J.-H. Son: bio115@kotmin.kr)

This is an Open Access article distributed under the terms of the Creative Commons Attribution Non-Commercial License (http://creativecommons. org/licenses/by-nc/3.0/) which permits unrestricted non-commercial use, distribution, and reproduction in any medium, provided the original work is properly cited.

\section{서 론}

피부는 시간이 지남에 따라 호르몬 분비가 감소하고, 면역세포 의 기능 활성이 저하되어 생체 구성 단백질들의 생합성이 줄어 들게 되어 생기는 내인성 노화와 외적으로 오염된 공기와 약물, 자외선에 의한 광노화로 나눠진다(Gilchrest, 1990; Ha, 2006).

노화가 진행될수록 피부를 구성하는 물질인 collagen, elastin, hyaluronic acid 등 구조 단백질을 생성하는 능력이 감소하고 type-1 collagenase의 생합성이 증가하여 matrix metalloproteinases (MMPs)의 발현이 증가되면 진피 내 교원 섬유, 탄력 섬유, fibronectin 및 laminin과 같은 기질 단백질 분해를 유도하여 피 부탄력을 떨어뜨리고 피부 주름생성을 야기한다(Brenneisen 등, 2002). 최근 연구에 의하면 elastase가 피부 탄력성 섬유의 3차 원적 뒤틀림에 중요한 역할을 한다고 보고 되어 있다(Philips 등, 2007). Elastase의 활성 증가는 피부 탄력 섬유를 감소시켜 피 부 주름 형성에 기여한다고 알려져 있으며 산화적 스트레스는 피부 노화를 더 촉진하게 된다(Emerit, 1992; Tsukahara 등, 2006). 피부 주름 개선 효과가 있는 다양한 소재 연구가 활발 하게 진행되고 있으며, 주름 개선으로 쓰이고 있는 물질로는 retinol, retinyl palmitate, adenosine, epigallocatechin gallate이 있다(Maeda 와 Fukada, 1991; Kim 등, 2010).

만형자(Vitex trifolia L.)는 마편초과의 순비기나무의 열매이다. 만형자의 기원 식물인 순비기나무는 독특하면서 강한 향기를 가 지고 있어 예전부터 잎과 가지는 목욕용 재료나 실내의 습기를 제거하기 위한 흡습제 및 방매제로 사용하였으며, 종자인 만형 자는 두통을 완화시키는 효과가 있다고 하여 민간에서는 베갯 속으로 사용하였다. 또한 우리나라를 포함한 중국과 일본 등 동 양의학에서 만형자는 성질이 차고 맛은 쓰면서 맵고 독이 없어 강장, 진정, 진통, 소염작용이 있어 감기, 만성중이염, 이명, 난 청, 시력장애, 두통, 신경통, 습진 및 다양한 염증과 알러지성 질환의 치료에 사용하고 있다(Park과 Lee, 2000). 만형자에 관 한 연구로는 monoterpene류를 포함한 약 76 종의 정유성분과 골 수성 백혈병 저해효과를 나타내는 flavonoids와 식물생장을 조 
절하는 phenol 화합물 등이 분리 동정된 바 있다(Kang과 $\mathrm{Kim}$, 1994; Ono 등, 2000; Xin 등, 2006). 따라서 본 연구에서는 만 형자 추출물의 피부노화를 억제시키는 항산화 효과와 피부탄력 및 주름 개선에 관련된 콜라겐 생합성 촉진 및 분해억제효능을 평가하여 기능성 화장품 원료로서의 사용 가능성을 살펴보고자 하였다.

\section{재료 및 방법}

실험재료. 본 실험에 사용한 만형자(Vitex trifolia L.)는 2014년 2월 초순에 (주)휴먼허브(Korea)에서 구입하여 실험 재료로 사 용하였다.

실험에 사용된 시약. 추출 및 용매 분획에 사용한 ethyl alcohol $(\mathrm{EtOH})$, n-hexane, ethyl acetate (EtOAc), methanol $(\mathrm{MeOH})$, n-butanol (n-BuOH) 등의 용매는 국내 덕산 $(18 \mathrm{~L}$, 공업용, Korea) 제품을 사용하였다. 항산화능 측정 실험과 주름억제 효과 측정에 사용된 시약인 1-1-diphenyl-2-picryl-hydrazyl (DPPH), 2,2'-azinobis(3-ethylbenzothiazoline-6-sulfonic acid) (ABTS), potassium persulfate, porcine pancreas elastase, n-succinyl-(L-Ala) $)_{3}$-nitroanilide, collagenase, 3-(4,5-dimethylthiazol-2-yl) 2,5-diphenyltetrazliumbromide (MTT) 등은 Sigma-Aldrich (USA)에서 구입하여 사용하였으며, MMP-1 활성을 측정하기 위하여 MMP-1 kit (Amersham Bioscience, USA), tumor necrosis factor- $\alpha$ (TNF- $\alpha$ )는 Sigma-Aldrich에서 구입하여 사용하였다.

추출 및 분획. 건조 된 시료 $300 \mathrm{~g}$ 을 분쇄기를 이용하여 잘게 파쇄한 후 $70 \%$ 에탄올을 $3 \mathrm{~L}$ 을 넣어 상온에서 24 시간씩 동일 용매로 3회 반복 추출한 다음 filter paper (Whatman No. 2, Japan)로 여과한 뒤 감압농축기를 이용하여 에탄올을 제거하여 농축액 $7.24 \mathrm{~g}$ 을 얻었다. 이후 용매추출법(solvent extraction method)을 이용하여 극성도가 낮은 n-hexane으로 추출한 후, 다 시 ethyl acetate와 butanol용매로 순차적으로 추출하였다. 각 용 매 추출 분획을 감압 농축하여 n-hexane 가용분획(약 $0.65 \mathrm{~g}$ ), $\mathrm{EtOAc}$ 분획(약 $1.21 \mathrm{~g}), \mathrm{n}-\mathrm{BuOH}$ 분획(약 $1.56 \mathrm{~g}), \mathrm{H}_{2} \mathrm{O}$ 가용분 (약 $1.02 \mathrm{~g}$ ) 각각 얻었다.

DPPH radical scavenging ability 측정. DPPH radical scavenging 에 대한 실험은 Blois의 방법(Blois, 1958)을 변형하여 96 well plate에 맞게 수정하여 측정하였다. 각 시료용액 $100 \mu \mathrm{L}$ 에 $0.2 \mathrm{mM}$ 의 $\mathrm{DPPH}$ 용액 $50 \mu \mathrm{L}$ 를 넣고 교반 한 후 10 분간 방치 한 다음 $517 \mathrm{~nm}$ 에서 흡광도를 측정하였으며, 시료용액의 첨가 구와 무첨가구 사이의 흡광도의 차이를 백분율로 나타냈다.

전자공여능 $(\%)=(1-$ 시료첨가군 흡광도/무첨가군 흡광도 $) \times 100$

ABTS radical scavenging activity 측정. ABTS radical scavenging 을 이용한 항산화력 측정은 ABTS radical scavenging ( $\operatorname{Re}$ 등, 1999)에 의하여 측정하였다.

$7 \mathrm{mM}$ 2,2'-azino-bis(3-ethylbenzothiazoline-6-sulfonic acid)와 $2.45 \mathrm{mM}$ potassium persulfate를 혼합하여 실온에서 24시간 동 안 방치하여 $\mathrm{ABTS}$ 를 형성시킨 후 ethanol로 희석하여 사용하 였다. 각 시료용액 $50 \mu \mathrm{L}$ 에 희석한 $\mathrm{ABTS}$ 용액 $100 \mu \mathrm{L}$ 를 가하 여 5 분 동안 방치한 후 $734 \mathrm{~nm}$ 에서 흡광도를 측정하였다.

전자공여능 $(\%)=(1-$ 시료첨가군 흡광도/무첨가군 흡광도 $) \times 100$

Elastase 저해활성 측정. Elastase 저해활성 측정은 Cannell의 방
법(Cannell 등, 1998)에 따라 측정하였다. 기질로서 n-succinyl(L-Ala) $)_{3}$-p-nitroanilide를 사용하여 $37^{\circ} \mathrm{C}$ 에서 30 분간 기질로부터 생성되는 p-nitroanilide의 생성량을 $445 \mathrm{~nm}$ 에서 측정하였다. 각 시료용액을 일정 농도가 되도록 조제하여 $40 \mu \mathrm{L}$ 씩 96 well plate에 취하고, $50 \mathrm{mM}$ tris- $\mathrm{HCl}$ buffer $(\mathrm{pH}$ 8.6)에 녹인 2.5 $\mathrm{U} / \mathrm{mL}$ porcine pancreas elastase용액을 $40 \mu \mathrm{L}$ 을 가한 후 기질로 $50 \mathrm{mM}$ tris-HCl buffer (pH 8.6)에 녹인 n-succinyl-(L-Ala) $)_{3}-\mathrm{p}$ nitroanilide $(0.5 \mathrm{mg} / \mathrm{mL})$ 을 첨가하여 30 분 간 반응시켜 측정하 였다. Elastase 저해활성은 시료용액의 첨가구와 무첨가구의 흡 광도 감소율로 나타내었다.

효소활성 저해 $(\%)=(1-$ 시료첨가군 흡광도/무첨가군 흡광도 $) \times 100$

세포주 배양. 본 실험에서 사용한 섬유아세포 CCD-986sk 세포 는 $\mathrm{ATCC}$ 에서 구입하여 사용하였다. 세포 독성 측정 및 배양을 위해 dulbecco's modified eagle medium (DMEM), fetal bovine serum (FBS), phosphate buffer solution (PBS), penicillin/streptomycin, $0.4 \%$ trypan blue stain은 Gibco BRL Co. (USA)에서 구입하였 으며, hemacytometer (Marienfeld, Germany), MMP-1 primary antibody와 secondary antibody는 santacruz (USA)에서 구입하 였다. 본 실험에 이용한 각 세포의 배양은 $10 \% \mathrm{FBS}$ 과 $1 \%$ penicillin/streptomycin $(100 \mathrm{U} / \mathrm{mL})$ 을 첨가한 DMEM 배지를 사 용하였으며, $37^{\circ} \mathrm{C}, 5 \% \mathrm{CO}_{2}$ incubator에 적응시켜 배양하였다. MTT assay에 의한 세포 생존율 측정. 세포를 96 well plate에 $5 \times 10^{3}$ cells/well이 되게 $180 \mu \mathrm{L}$ 씩 분주하고, $\mathrm{PBS}$ 을 첨가한 다음 자외선을 조사하고 시료를 농도 별로 $20 \mu \mathrm{L}$ 처리한 후 $37^{\circ} \mathrm{C}$, $5 \% \mathrm{CO}_{2}$ incubator에서 48시간 배양 하였다. 배양 후 $5 \mathrm{mg} / \mathrm{mL}$ 농도로 제조한 $\mathrm{MTT}$ 용액 $20 \mu \mathrm{L}$ 를 첨가하여 3시간 배양한 후 배양액을 제거하고 각 well당 DMSO $150 \mu \mathrm{L}$ 를 가하여 실온에 서 30 분간 반응 시킨 뒤 microplate reader (Gen5, Bio-Tak Instruments, Inc., USA)로 $540 \mathrm{~nm}$ 에서 흡광도를 측정하였다.

MMP-1 저해활성 측정. 96 well plate에 각 well당 $1 \times 10^{5}$ cells/well 세포가 되도록 심어준 후 24시간을 안정화 하였다. 이 후, 배양된 배지를 제거하고 $\mathrm{PBS}$ 을 첨가한 다음 자외선을 조 사하고 이때 MMP-1의 활성을 높이기 위하여 TNF- $\alpha$ 를 $10 \mathrm{ng} /$ $\mathrm{mL}$ 의 농도로 첨가하고 시료를 농도 별로 처리한 후 48시간을 배양하였다. 세포의 배양액을 수거하여 실험에 사용하였으며 Gross B.E. 등의 방법(Gross와 Lapiere, 1962)에 따라 MMP-1 biotrack activity assay kit (Amersham Bioscience, USA)을 이 용하여 측정하였다.

Western blot을 이용한 단백질의 발현 측정. MMP-1 활성을 보 기 위하여 cell line (CCD-986sk)을 6 well에 $1 \times 10^{5}$ cells/well 이 되도록 분주하고 24 시간 동안 배양하였다. 배지를 제거한 후 각 well에 시료를 48시간 동안 처리한 뒤 PBS로 2번 세척해주 었다. Lysis buffer를 이용하여 CCD-986sk 세포를 용해시키고, $4^{\circ} \mathrm{C} 12,000 \mathrm{rpm}$ 에서 20 분간 원심 분리하였다. 원심 분리하여 얻 은 상층액은 Bradford assay로 정량하여 $20 \mu \mathrm{g}$ 의 단백질을 $10 \%$ 의 sodium dodecyl sulfate polyacrylamide gel electrophoresis gel에서 전기영동하여 분리하였다. 분리된 단백질은 $\mathrm{PVDF}$ membrane에 옮긴 다음 실온에서 1시간 blocking buffer $(5 \%$ skim milk in TBST)에서 incubation시켰다. MMP-1 각각의 1 차 항체를 $1: 1000$ 으로 희석하여 $4^{\circ} \mathrm{C}$ 에서 over night한 다음, 다 시 10 분 간격으로 TBST로 3 회 washing하고 mouse anti-rabbit $\mathrm{IgG} \mathrm{HRP}$ 의 각각의 2차 항체를 $1: 1,000$ 로 희석하여 실온에서 1 시간 동안 붙이고, 3회 washing한 뒤 LAS 4,000 image 


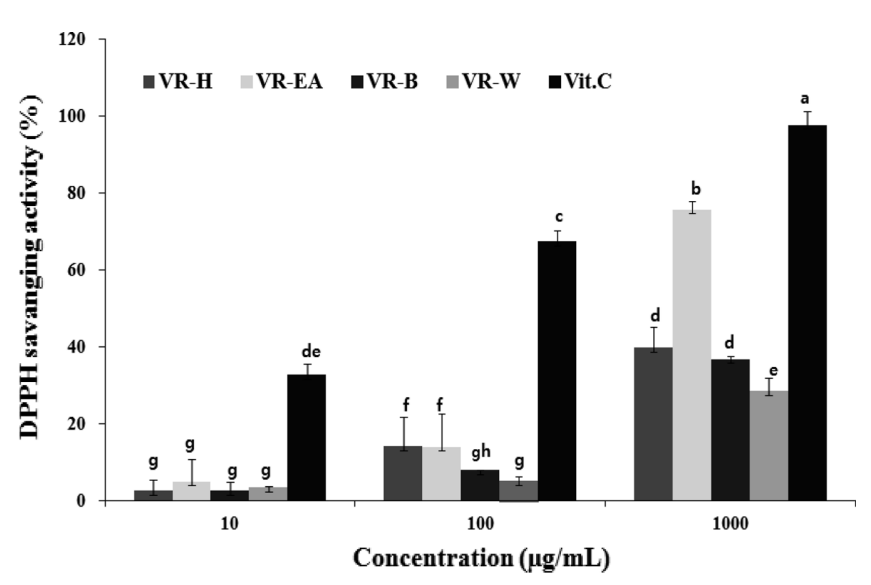

Fig. 1 DPPH scavenging activity of fractions from Vitex trifolia L.. VRH: Hexane layer, VR-EA: Ethyl acetate layer, VR-B: Butanol layer, VRW: Water layer, vit. C: Ascorbic acid. Values are means of 3 replicates and those with different alphabet letters are significantly different at $p<0.05$.

analyzer (Fugifilm life science, Japan) 기기를 이용하여 밴드 확인 및 정량하였다.

통계처리. 결과 통계처리는 SPSS 10.0 을 사용하였으며, 유의차 검증은 분산분석(ANOVA: analysis of variance) 프로그램을 이 용하여 t-test를 이용하여 통계적 유의수준 $p<0.05$ 에서 검증하 였다.

\section{결과 및 고찰}

DPPH radical scavenging ability 측정. DPPH는 짙은 보라색 을 띄는 비교적 안정한 free radical로서 항산화제, 방향족 아민 류 등에 의해 환원되어 색이 탈색이 되는데 이것은 다양한 천 연소재로부터 항산화 물질을 탐색하는데 많이 이용되고 있다 (Kim 등, 1995; Aoshima 등, 2004). 본 실험에서는 만형자 분 획물의 항산화 효과를 알아보기 위하여 $\mathrm{DPPH}$ 를 이용하여 항 산화 효과를 측정한 결과(Fig. 1), $1,000 \mu \mathrm{g} / \mathrm{mL}$ 에서 $\mathrm{n}$-hexane 분획물의 경우 $46 \%$, ethyl acetate 분획물 $76 \%$, butanol 분획 물 $37 \%$, water 분획물이 $29 \%$ 를 나타내었으며, 대조군인 vitamin C (vit. C)에서는 $1000 \mu \mathrm{g} / \mathrm{mL}$ 에서 $95 \%$ 의 전자공여능을 나타내었다. 만형자 ethyl acetate 분획물에서 DPPH free radical 소거율이 높게 나타나는 것을 확인할 수 있었다.

ABTS radical scavenging activity 측정. ABTS radical scavenging 는 $\mathrm{ABTS}$ 와 potassium persulfate와의 반응으로 생성된 $\mathrm{ABTS}^{+}$ radical이 시료중의 항산화 물질에 의해 제거되어 radical 특유의 청록색이 탈색되는 정도를 $734 \mathrm{~nm}$ 에서 흡광도를 측정하였다 (Jeong 등, 1994). 만형자 분획물의 ABTS radical scavenging 을 측정한 결과(Fig. 2), $1,000 \mu \mathrm{g} / \mathrm{mL}$ 에서 $\mathrm{n}$-hexane 분획물의 경우 $47 \%$, ethyl acetate 분획물 $89 \%$, butanol 분획물 $72 \%$, water 분획물이 $52 \%$ 를 나타내었으며, 대조군인 vit. C에서는 $1,000 \mu \mathrm{g} / \mathrm{mL}$ 에서 $95 \%$ 의 전자공여능을 나타내었다. 만형자 분획 물 중 ethyl acetate 분획물이 가장 강한 활성을 나타내는 것을 확인할 수 있었다.

Elastase 활성 저해효과. Elastase는 단백질인 엘라스틴을 분해 하는 효소로 다른 중요한 기질 단백질인 콜라겐을 분해할 수

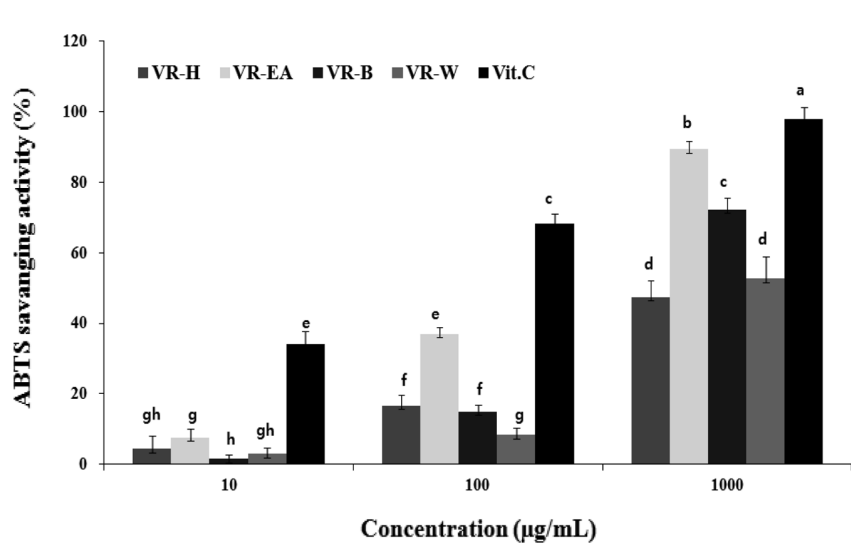

Fig. 2 ABTS cation radical activity of fractions from Vitex trifolia L.. VR-H: Hexane layer, VR-EA: Ethyl acetate layer, VR-B: Butanol layer, VR-W: Water layer, vit. C: Ascorbic acid. Values are means of 3 replicates and those with different alphabet letters are significantly different at $p<0.05$.

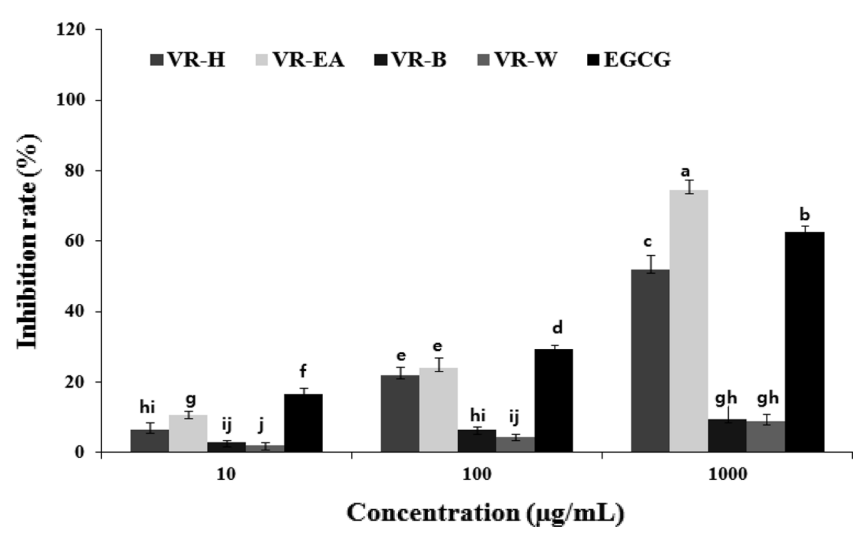

Fig. 3 Elastase inhibition rate of fractions from Vitex trifolia L.. VR-H: Hexane layer, VR-EA: Ethyl acetate layer, VR-B: Butanol layer, VR-W: Water layer, EGCG: Epigallocate chin-3-gallate. Values are means of 3 replicates and those with different alphabet letters are significantly different at $p<0.05$.

있는 비특이적 가수 분해 효소이다. 피부의 진피조직 속에서는 콜라겐과 피부의 탄력성에 관련된 엘라스틴이 그물망 구조로 형 성하고 있는데, 엘라스틴이 elastase에 의해 분해되어 피부의 그 물망 구조 결합이 끊어짐으로, elastase가 주름생성의 주원인 효 소로 알려져 있다(Kligman, 2000). 이러한 주름 생성과 관련된 elastase 저해활성을 측정한 결과(Fig. 3), 만형자 분획물 $1,000 \mu \mathrm{g} / \mathrm{mL}$ 에서 butanol 분획물 $9 \%$, water 분획물 $8 \%$ 의 낮은 활성을 나타낸 반면 $\mathrm{n}$-hexane 분획 물에서는 $1,000 \mu \mathrm{g} / \mathrm{mL}$ 농도 에서 $52 \%$ 저해활성을 나타내었고, 특히 만형자 ethyl acetate 분획물의 경우 $1,000 \mu \mathrm{g} / \mathrm{mL}$ 농도에서 $74 \%$ 저해활성을 나타내 었다. 동일 농도 대조군인 EGCG (Epigallocatechin-3-gallate)와 비교시 같은 농도에서 elastase 저해활성이 $62 \%$ 나타내었다. 만형 자 ethyl acetate 분획물이 대조군인 EGCG보다 elastase 저해활 성이 더욱 우수하는 것을 확인 할 수 있었다.

Fibroblast cell (CCD-986sk)의 생존율 확인. 섬유아세포에서 만형자 분획물의 처리가 세포 증식에 미치는 영향을 확인하기 위하여 MTT assay를 이용한 세포 생존율을 측정하였다(Fig. 4). 만형자 n-hexane, ethyl acetate, butanol, water 분획물을 농도 


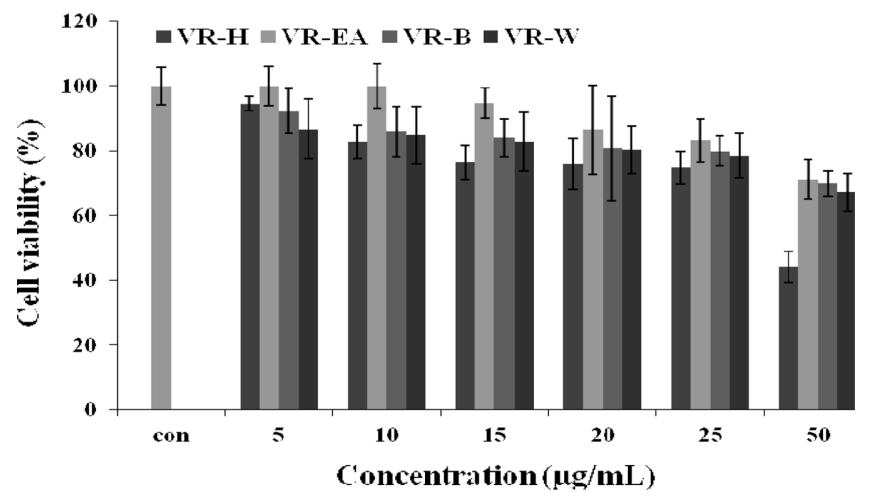

Fig. 4 Cell viability effects of Vitex trifolia L. fractions on fibroblast cell (CCD-986sk). CCD-986sk cells $\left(5 \times 10^{3}\right.$ cells) were started in medium for $24 \mathrm{~h}$ the cells were treated with $5,10,15,20,25 \mu \mathrm{g} / \mathrm{mL}$ of fractions of Vitex trifolia L. for 48 h. VR-H: Hexane layer, VR-EA: Ethyl acetate layer, VR-B: Butanol layer, VR-W: Water layer.

별로 48 시간 처리한 결과 ethyl acetate 분획물 $5,10,15,20$, $25 \mu \mathrm{g} / \mathrm{mL}$ 농도구간에서 $100 \%$ 에 가까운 세포 생존율을 확인 하 였다. 따라서 본 실험에서는 섬유아세포에 만형자 분획물 5,10 , $25 \mu \mathrm{g} / \mathrm{mL}$ 의 농도로 처리하여 MMP-1 저해활성 측정과 단백질 발현 실험을 하였다.

MMP-1 저해활성 측정. 체내에서 생성되는 수종의 MMPs 가 운데 MMP-1은 collagen에 특이적으로 작용하는 protease로서 MMP-1의 활성을 억제하여 collagen의 분해를 감소시키면, 피부 조직의 탄력을 유지하고 주름생성을 예방할 수 있는 것으로 알 려져 있다(Talwar 등, 1995; Nagase와 Woessner, 1999). 본 연 구에서 만형자 분획물이 MMP-1 생성에 미치는 영향을 평가한 결과(Fig. 5), UV-B를 처리하지 않은 군과 처리한 군은 각각 $52,100 \%$ 의 MMP- 1 을 생산하여 UV-B를 처리함으로써 MMP1 양이 활성화됨을 확인할 수 있었다. 만형자 ethyl acetate 분 획물 $25 \mu \mathrm{g} / \mathrm{mL}$ 에서 $14 \%$ 의 MMP- 1 의 발현 저해효과를 나타내 었다. 본 연구 결과를 통해 만형자 ethyl acetate 분획물이 피부 탄력 및 주름 개선 효능에 기여할 것으로 판단된다.

MMP-1 유전자 발현의 억제. MMPs는 활성 중심부에 아연을 갖는 금속 단백질 분해 효소로서 현재까지 약 20 여 종 이상의 종류가 있는 것으로 알려져 있으며, 구조와 기능에 따라 interstitial, collagenase, gelatinase, stromelysin, membrane type MMP 등으로 구분하기도 한다(Nagase와 Woessner, 1999). MMP1은 collagenase 1으로 알려져 있으며, type I과 III collagen을 기질로 하며, stromelysin 1라고도 불리는 MMP-3은 기저막의 type IV collagen을 분해하며 zymogen인 pro MMP-1을 활성화 시키는데, 이러한 MMPs의 발현증가는 자외선에 의해 유도된다 (Fisher, 1996). 본 연구에서는 MMPs family중 MMP-1의 단백 질 발현을 보기 위하여 MMP-1의 단백질 발현을 만형자 ethyl acetate 분획물 처리군에서 MMP-1의 protein 발현 모두 5, 10 , $25 \mu \mathrm{g} / \mathrm{mL}$ 의 농도 의존적으로 억제 되는 것을 확인하였다(Fig. 6). 따라서 만형자 ethyl acetate 분획물이 주름생성 억제 활성 을 보이는 것으로 판단된다.

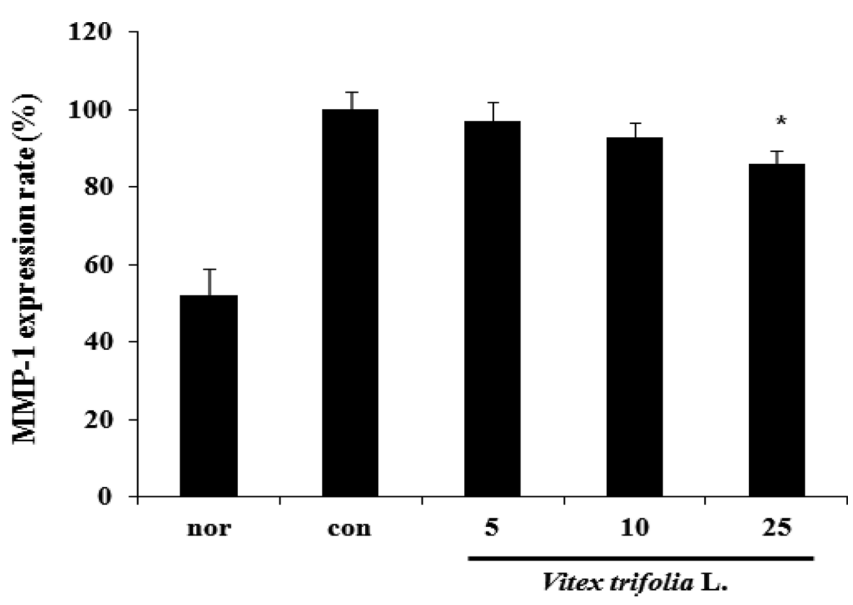

Concentration $(\mu \mathrm{g} / \mathrm{mL})$

Fig. 5 MMP-1 inhibition rate of ethyl acetate fraction from Vitex trifolia L. on fibroblast cell (CCD-986sk). The cells were treated with various concentrations of ethyl acetate fraction for $48 \mathrm{~h}$. The contents of MMP-1 in culture media was determined by the MMP-1 ELISA kit as detailed under the materials and methods. The data represent the mean $\pm \mathrm{SD}$ of three separate experiments (Significant as compared to control. ${ }^{*} p<0.05$ ).

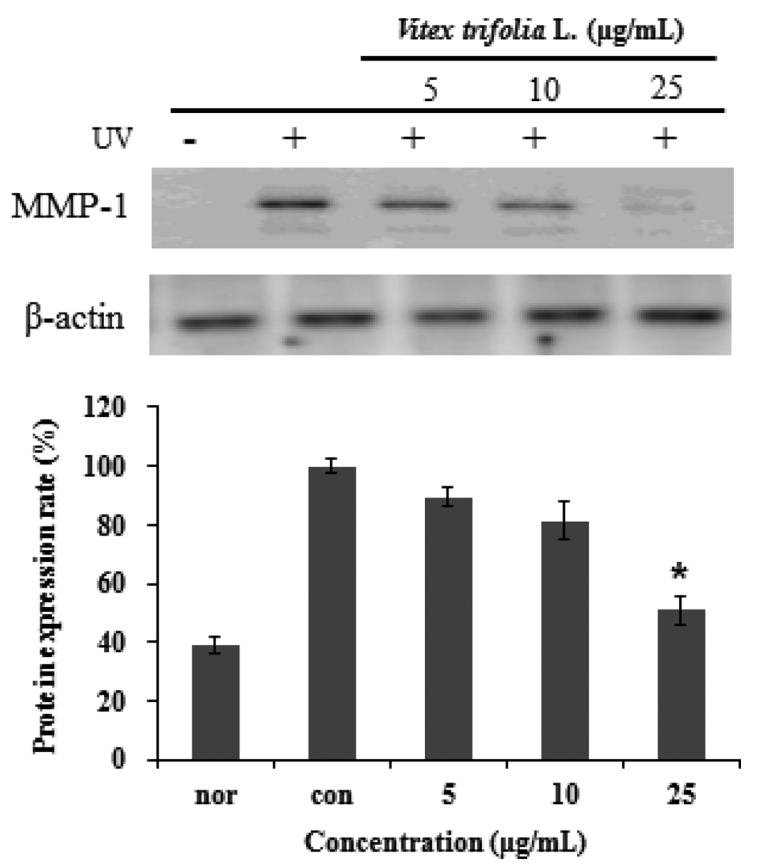

Fig. 6 MMP-1 protein expression rate of Vitex trifolia L. on fibroblast cell (CCD-986sk). CCD-986sk cells $\left(1 \times 10^{5}\right.$ cells) were started in medium for $24 \mathrm{~h}$. The cells were treated with $5,10,25 \mu \mathrm{g} / \mathrm{mL}$ of ethyl acetate fraction of Vitex trifolia L. for $48 \mathrm{~h}$. Histogram show the densitometry of MMP-1 protein normalized to $\beta$-actin. The data represent the mean \pm SD of three separate experiments (Significant as compared to control. $\left.{ }^{*} p<0.05\right)$. 


\section{초 록}

본 연구에서는 만형자 분획물의 항산화 및 주름개선 효과에 대 하여 알아보고자 하였다. 만형자 ethyl acetate 분획물은 DPPH, $\mathrm{ABTS}$ 에서 우수한 항산화 활성을 나타내었으며, 주름개선 효과 를 검증하기 위하여 elastase 저해활성을 측정한 결과 $1,000 \mu \mathrm{g}$ $\mathrm{mL}$ 에서 $74 \%$ 저해활성을 나타내었다. 만형자 ethyl acetate 분 획물의 세포생존율을 확인하기 위하여 섬유아세포로 MTT assay 에 의해 확인 한 결과 $5,10,15,20,25 \mu \mathrm{g} / \mathrm{mL}$ 의 농도구간에 서 $100 \%$ 에 가까운 세포 생존율을 확인하였다. 만형자 ethyl acetate 분획물의 MMP-1 저해활성을 측정 한 결과 $25 \mu \mathrm{g} / \mathrm{mL}$ 에 서 $14 \%$ 의 저해효과를 나타내었으며, 만형자 ethyl acetate 분획 물의 MMP-1의 단백질 발현 억제 효과를 확인한 결과 $25 \mu \mathrm{g}$ $\mathrm{mL}$ 의 농도에서 $50 \%$ 감소하였다. 이러한 결과로 보아 만형자 ethyl acetate 분획물의 주름개선 효과를 확인할 수 있으며, 천 연 기능성 화장품 소재로서의 가능성을 확인하였다.

Keywords 1-1-diphenyl-2-picryl-hydrazyl $\cdot 2,2$ '-azino-bis(3ethylbenzothiazoline-6-sulfonic acid) $\cdot$ anti-wrinkle $\cdot$ elastase $\cdot$ matrix metalloprotease $-1 \cdot$ Vitex trifolia $\mathrm{L}$.

\section{References}

Aoshima H, Tsunoue H, Koda H, and Kiso Y (2004) Aging of whiskey increases 1,1 diphenyl-2picrylhydrazyl radical scavenging activity. $J$ Agric Food Chem 52, 5240-4.

Blois MS (1958) Antioxidant determinations by the use or a stable free radical. Nature 181, 1199-200.

Brenneisen P, Sies H, and Scharffetter-Kochanek K (2002) Ultraviolet-B irradiation and matrix metalloproteinases:from induction via signaling to initial events. Ann N Y Acad Sci 973, 31-43.

Cannell RJ, Kellam SJ, Owsianka AM, and Walker JM (1998) Results of a large scale screen of microalgae for the production of protease inhibitors. Planta Med 54, 10-4.

Emerit I (1992) Free radicals and aging of the skin. In Free Radicals and Aging, Emerit I and Chance B (eds), pp. 328-41, Experientia Supplementum, Birkhauser Basel, Switzerland.

Fisher GJ, Datta SC, Talwar HS, Wang ZQ, Varani J, and Kang S (1996)
Molecular basis of sun-induced premature ageing and retinoid antagonism. Nature 379, 335-9.

Gilchrest BA (1990) Skin aging and photoaging. Dermatol Nurs 2, 79-82.

Gross J and Lapiere CM (1962) Collagenolytic activity in amphibian tissues: a tissue culture assay. Proc Natl Acad Sci USA 54, 1197-204.

Ha TY (2006) Development of functional food materials for healthy life. Korean J Crop Sci 51, 26-39.

Jeong JW, Lee YC, Jung SW, and Lee KM (1994) Flavor components of citron juice as affected by the extraction method. Korean J Food Sci Technol 26, 709-12.

Kang SS and Kim SJ (1994) Phytochemical Analysis of Viticis Fructus. Korean J Pharmaco gn 98, 214-20.

Kim BY, Kim TG, Kang WY, Baek H, Cheon HY, and Kim D (2010) Functional cosmetic effect of porcine placenta. Korean Chem Eng Res 48, 327-31.

Kim HK, Kim YE, Do JR, Lee YC, and Lee BY (1995) Antioxidative activity and physiological activity of some Korean medicinal plants. Korean $J$ Food Sci Technol 27, 80-5.

Kli gman D (2000) Cosmeveuticals. Dermatol Clin 18, 609-15.

Maeda K and Fukada M (1991) In vitro effectiveness of several whitening cosmetic components in human melanocytes. J Soc Cosmet Chem 42, 361-8.

Nagase H and Woessner JF (1999) Matrix metalloproteinases. J Biol Chem 274, 21491-4.

Ono M, Sawamura H, Ito Y, and Mizuki K (2000) Diterpenoids from the fruits of Vitex trifolia. Phytochemistry 55, 873-7.

Park JH and Lee CK (2000) The Encyclopedia of Medicinal Plants. Shinilbooks. Korea.

Philips N, Keller T, Hendrix C, Hamilton S, Arena R, Tuason M et al. (2007) Regulation of the extracellular matrix remodeling by lutein in dermal fibroblasts, melanoma cells, and ultraviolet radiation exposed fibroblasts. Arch Dermatol Res 299, 373-9.

Re R, Pellegrini N, Proteggente A, Yang M, and Rice-Evans C (1999) Antioxidant activity applying an improved ABTS radical cation decolorization assay. Free Radical Biol Med 26, 1231-7.

Talwar HS, Griffiths CE, Fisher GJ, Hamilton TA, and Voorhees JJ (1995) Reduced type I and type III procollagens in photodamaged adult human skin. J Invenst Dermatol 105, 285-90.

Tsukahara K, Nakagawa H, Moriwaki S, Takema Y, Fujimura T, and Imokawa G (2006) Inhibition of ultraviolet-B-induced wrinkle formation by an elastase-inhibiting herbal extract: implication for the mechanism underlying elastase-associated wrinkles. Int J Dermatol 45, 460-8.

Xin YH, Zhang QY, and Huang BK (2006) Study on chemical constituents in fruits of Vitex trifolia L. var. simplicifolia Cham. Arch Pharm Res 29, 747-9. 